\title{
Perbandingan efektivitas dental health education metode ceramah dan metode permainan simulasi terhadap peningkatan pengetahuan kesehatan gigi dan mulut anak
}

\author{
${ }^{1}$ Retno Puspitaningtiyas \\ ${ }^{2}$ Michael A. Leman \\ ${ }^{2}$ Juliatri
}

\author{
${ }^{1}$ Kandidat Skripsi Program Studi Pendidikan Dokter Gigi Fakultas Kedokteran \\ ${ }^{2}$ Program Studi Pendidikan Dokter Gigi Fakultas Kedokteran \\ Universitas Sam Ratulangi Manado \\ Email: retnotiyasretnotiyas@yahoo.co.id
}

\begin{abstract}
Indonesia has a prevalence of oral health problems which is continuously increasing, mostly among children. The two dominating diseases namely dental caries and periodontal disease. Factor that influences both diseases is behavior. Intervention through education with the use of appropriate methods and media can improve children's knowledge. This study was aimed to compare the effectiveness of dental health education (DHE) using lecture method and simulation game in increasing the knowledge of oral health of children. This was a quasi experimental study with a non-equivalent control group design. Respondents were students of SDN Mantelagheng aged 10-12 years old as many as 56 students obtained by using total sampling method. Respondents were divided into two groups: lecture and simulation game, each of 27 students. The results showed that the DHE in lecture and simulation game groups could significantly increase the children's knowledge about oral health $(p=0.000)$. The Mann-Whitney test showed a significant difference in effectiveness between the two groups $(p=0.000)$. The average value of the lecture group was 16.52 meanwhile of the simulation group 38.48. Conclusion: Simulation game method was more effective to improve the oral health knowledge of children than the lecture method.
\end{abstract}

Keywords: dental health education, knowledge

\begin{abstract}
Abstrak: Indonesia memiliki prevalensi masalah kesehatan gigi dan mulut yang terus meningkat, dan sebagian besar terjadi pada anak-anak. Dua penyakit yang mendominasi, yaitu karies gigi dan penyakit periodontal. Faktor yang berpengaruh pada kedua penyakit ini yaitu perilaku. Intervensi melalui pendidikan dengan penggunaan metode dan media yang tepat, dapat dilakukan untuk meningkatkan pengetahuan anak. Penelitian ini bertujuan untuk mengetahui perbandingan efektivitas dental health education (DHE) metode ceramah dan permainan simulasi terhadap peningkatan pengetahuan kesehatan gigi dan mulut anak. Jenis penelitian ialah quasi experimental dengan rancangan non equivalent control group. populasi penelitian yaitu siswa SDN Mantelagheng yang berusia 10-12 tahun. Terdapat 56 siswa sebagai responden, diperoleh dengan metode total sampling, dibagi dalam dua kelompok yakni ceramah dan permainan simulasi masing-masing 27 responden. Hasil penelitian menunjukkan DHE pada kelompok ceramah dan permainan simulasi terhadap peningkatan pengetahuan tentang kesehatan gigi dan mulut masing-masing mendapatkan $\mathrm{p}=0,000$. Hasil uji MannWhitney menunjukkan perbandingan bermakna antara efektivitas kedua kelompok $(\mathrm{p}=0,000)$, dengan nilai rerata kelompok ceramah 16,52 dan kelompok permainan simulasi 38,48. Simpulan: Metode permainan simulasi lebih efektif terhadap peningkatan pengetahuan kesehatan gigi dan mulut anak dibandingkan dengan metode ceramah.
\end{abstract}

Kata kunci: dental health education, pengetahuan 
Kesehatan gigi dan mulut merupakan hal yang sangat penting dan apabila terjadi masalah pada kesehatan gigi dan mulut, hal ini dapat mengganggu kesehatan secara umum. ${ }^{1}$ Masalah kesehatan gigi dan mulut, dapat terjadi pada semua kelompok usia baik dewasa maupun anak-anak. Pada anak-anak, masalah kesehatan gigi dan mulut dapat berpengaruh pada pertumbuhan dan perkembangan anak.

Penduduk Indonesia sampai saat ini, masih mengalami masalah kesehatan gigi dan mulut. Hal ini dapat dilihat dari prevalensi masalah kesehatan gigi dan mulut yang terus meningkat. Berdasarkan hasil Riset Kesehatan Dasar (RISKESDAS) tahun 2007 dan 2013, prevalensi rata-rata penduduk Indonesia yang memiliki masalah kesehatan gigi dan mulut meningkat dari $23,4 \%$ menjadi $25,9 \%$, sedangkan berdasarkan karakteristik usia yaitu pada anak berusia 5-9 tahun dari 21,6 menjadi $28,9 \%$, dan anak berusia 10-14 tahun dari $20,6 \%$ menjadi $25,9 \%$. $^{1,2}$

Masalah kesehatan gigi dan mulut yang paling mendominasi pada anak-anak, yaitu karies dan penyakit periodontal. Karies dan penyakit periodontal pada anak dipengaruhi oleh beberapa faktor, salah satunya yaitu faktor perilaku. Data RISKESDAS tahun 2007 dan 2013 menyebutkan bahwa prevalensi penduduk berusia 10 tahun ke atas yang menyikat gigi dengan benar dari 3,5\% di tahun 2007 menurun menjadi $1,7 \%$ di tahun 2013. ${ }^{1,2}$ Hasil riset tersebut menggambarkan bahwa perilaku anak Indonesia dalam menjaga kesehatan gigi dan mulut masih rendah. Hal tersebut menjadi masalah, karena salah satu cara yang efektif dalam pencegahan penyakit karies dan penyakit periodontal, yakni dengan menyikat gigi. Terbentuknya perilaku menyikat gigi individu dengan benar, perlu didasari dengan pengetahuan yang dimiliki individu melalui pendidikan. ${ }^{3}$

Pendidikan kesehatan gigi dan mulut atau dental health education (DHE) merupakan proses pendidikan yang bertujuan untuk meningkatkan kesehatan gigi dan mulut. Dalam proses ini seseorang dapat memperoleh pengetahuan berupa informasi melalui media pendidikan yang ada. Media pendidikan merupakan alat bantu dalam suatu proses pendidikan. Salah satu landasan teori penggunaan metode dan media dalam proses pendidikan, yakni teori Dale's cone experience (Kerucut pengalaman Dale) tahun 1969. Menurut teori tersebut, terdapat beberapa metode yang dapat digunakan dalam proses pendidikan. Pada dasarnya proses pendidikan yang melibatkan lebih banyak indera akan lebih mudah untuk diterima dan diingat oleh individu. Pemberian pendidikan kesehatan gigi dan mulut akan lebih efektif dan optimal dengan menggunakan metode dan media yang tepat. ${ }^{4-6}$

Hasil penelitian yang dilakukan Sumantri et al. $^{7}$ tentang pengaruh perubahan tingkat pengetahuan kesehatan gigi dan mulut pada pelajar melalui permainan edukasi kedokteran gigi, menunjukkan bahwa metode simulasi dan demonstrasi yang menggunakan media ular tangga memberikan pengaruh yang lebih baik dalam meningkatkan pengetahuan kesehatan gigi dan mulut, sehingga dapat menjadi salah satu metode pendidikan kesehatan gigi dan mulut.

Penelitian ini bertujuan untuk mengetahui perbandingan efektivitas dental health education metode ceramah dan permainan simulasi terhadap peningkatan pengetahuan kesehatan gigi dan mulut anak.

\section{METODE PENELITIAN}

Jenis penelitian ini ialah quasi experimental dengan rancangan penelitian non equivalent control group. Penelitian ini dilakukan di SDN Mantelagheng, Kecamatan Tamako, Kabupaten Kepulauan Sangihe, Provinsi Sulawesi Utara pada bulan Agustus - November 2016. Populasi penelitian ini ialah murid SDN Mantelagheng yang berusia 10-12 tahun berjumlah 56 siswa. Sesuai dengan kriteria inklusi, jumlah sampel pada penelitian ini sebanyak 54 responden, yang kemudian dibagi dalam dua kelompok masing-masing 27 responden. Penilaian tingkat 
pengetahuan kesehatan gigi dan mulut dilakukan dengan kuesioner tingkat pengetahuan kesehatan gigi dan mulut. Data diolah menggunakan SPSS dengan uji Mann-Whitney, dan disajikan dalam bentuk tabel distribusi.

\section{HASIL PENELITIAN}

Distribusi frekuensi responden berdasarkan jenis kelamin dan usia dapat dilihat pada Tabel 1 dan 2 .

Tabel 1. Distribusi frekuensi responden berdasarkan jenis kelamin

\begin{tabular}{|c|c|c|c|c|}
\hline \multirow{3}{*}{$\begin{array}{c}\text { Jenis } \\
\text { kelamin }\end{array}$} & \multicolumn{4}{|c|}{ Kelompok } \\
\hline & \multirow{2}{*}{\multicolumn{2}{|c|}{$\begin{array}{c}\text { Ceramah } \\
\text { Frekuensi } \\
(\%)\end{array}$}} & \multirow{2}{*}{\multicolumn{2}{|c|}{$\begin{array}{c}\begin{array}{c}\text { Permainan } \\
\text { simulasi }\end{array} \\
\begin{array}{c}\text { Frekuensi } \\
(\%)\end{array} \\
\end{array}$}} \\
\hline & & & & \\
\hline Laki-Laki & 15 & 55,6 & 16 & 59,3 \\
\hline Perempuan & 12 & 44,4 & 11 & 40,7 \\
\hline Total & 27 & 100 & 27 & 100 \\
\hline
\end{tabular}

Tabel 2. Distribusi frekuensi responden berdasarkan usia

\begin{tabular}{ccccc}
$\begin{array}{c}\text { Usia } \\
\text { (tahun) }\end{array}$ & \multicolumn{3}{c}{ Kelompok } \\
\cline { 2 - 5 } & Ceramah & $\begin{array}{c}\text { Permainan } \\
\text { simulasi }\end{array}$ \\
\cline { 2 - 5 } & \multicolumn{2}{c}{$\begin{array}{c}\text { Frekuensi } \\
(\%)\end{array}$} & \multicolumn{2}{c}{$\begin{array}{c}\text { Frekuensi } \\
(\%)\end{array}$} \\
\hline 10 & 16 & 59,3 & 16 & 59,3 \\
11 & 8 & 29,6 & 8 & 29,6 \\
12 & 3 & 11,1 & 3 & 11,1 \\
Total & 27 & 100 & 27 & 100 \\
\hline
\end{tabular}

Tabel 3 memperlihatkan hasil pengukuran tingkat pengetahuan pre dan post test. Hasil uji Wilcoxon pada kedua kelompok dapat dilihat pada Tabel 4 dan 5 sedangkan hasil uji Mann-Whitney antara kedua kelompok perlakuan dapat dilihat pada Tabel 6 .
Tabel 3. Hasil pengukuran tingkat pengetahuan anak

\begin{tabular}{|c|c|c|c|c|}
\hline \multirow{3}{*}{$\begin{array}{l}\text { Item } \\
\text { pertanyaan }\end{array}$} & \multicolumn{4}{|c|}{ Kelompok } \\
\hline & \multicolumn{2}{|c|}{ Ceramah } & \multicolumn{2}{|c|}{$\begin{array}{c}\text { Permainan } \\
\text { simulasi }\end{array}$} \\
\hline & $\begin{array}{l}\text { Pre- } \\
\text { test }\end{array}$ & $\begin{array}{c}\text { Post- } \\
\text { test }\end{array}$ & $\begin{array}{l}\text { Pre- } \\
\text { test }\end{array}$ & $\begin{array}{c}\text { Post- } \\
\text { test }\end{array}$ \\
\hline 1 & 54 & 54 & 54 & 54 \\
\hline 2 & 53 & 54 & 54 & 54 \\
\hline 3 & 54 & 54 & 53 & 54 \\
\hline 4 & 54 & 54 & 54 & 54 \\
\hline 5 & 51 & 53 & 51 & 54 \\
\hline 6 & 50 & 53 & 51 & 54 \\
\hline 7 & 30 & 40 & 32 & 51 \\
\hline 8 & 33 & 33 & 34 & 47 \\
\hline 9 & 34 & 46 & 34 & 47 \\
\hline 10 & 30 & 35 & 30 & 45 \\
\hline 11 & 33 & 53 & 33 & 51 \\
\hline 12 & 44 & 53 & 49 & 52 \\
\hline Total skor & 520 & 582 & 525 & 617 \\
\hline Selisih & 62 & & 92 & \\
\hline
\end{tabular}

Tabel 4. Uji Wilcoxon kelompok ceramah

\begin{tabular}{lllll}
\hline Kelompok & n & Mean & Std & Sig. \\
\hline Pre-test & 27 & 19,26 &, 859 & \\
& & & &, 000 \\
Post-test & 27 & 20,96 &, 854 & \\
\hline
\end{tabular}

Tabel 5. Uji Wilcoxon kelompok permainan simulasi

\begin{tabular}{lllll}
\hline Kelompok & n & Mean & Std & Sig. \\
\hline Pre-test & 27 & 19,89 &, 974 & \\
& & & &, 000 \\
Post-test & 27 & 23,00 &, 784 & \\
\hline
\end{tabular}

Tabel 6. Uji Mann-Whitney antara kelompok ceramah dan permainan simulasi

\begin{tabular}{lllll}
\hline Kelompok & n & Mean & Df & Sig. \\
\hline Ceramah & 27 & 16,52 & & \\
$\begin{array}{l}\text { Permainan } \\
\text { simulasi }\end{array}$ & 27 & 38,48 & 54 &, 000 \\
\hline
\end{tabular}




\section{BAHASAN}

Hasil penelitian ini menunjukkan bahwa terdapat perbedaan antara tingkat pengetahuan anak pre-test (sebelum) dan post-test (sesudah) pada kelompok ceramah dan kelompok permainan simulasi yang diberikan dental health education metode simulasi dengan permainan ular tangga. Hal tersebut ditunjukkan dengan adanya selisih nilai antara pre-test dan post-test pada kelompok ceramah sebanyak 62, sedangkan pada kelompok permainan simulasi sebanyak 92. Data ini menunjukkan bahwa terdapat peningkatan yang lebih tinggi pada kelompok permainan simulasi yang diberikan dental health education dengan permainan ular tangga dibandingkan kelompok ceramah terdapat selisih skor sebanyak 30. Hal ini menunjukkan metode simulasi dengan permainan ular tangga mampu membuat suasana belajar yang pasif menjadi aktif, anak-anak bergerak menjadi riang, sehingga anak mampu menangkap lebih banyak pesan atau informasi yang disampaikan lewat permainan ular tangga. ${ }^{8}$

Berdasarkan hasil uji Wilcoxon pada kelompok ceramah (Tabel 6) dan kelompok permainan simulasi (Tabel 7), perlakuan menunjukkan $\mathrm{p}=0,000 \quad(\mathrm{p}<0,05) \quad$ yang berarti terdapat perbedaan nilai hasil pengukuran tingkat pengetahuan anak sebelum (pre-test) dan sesudah (post-test) diberikan dental health education dengan metode simulasi menggunakan permainan ular tangga. Dengan demikian hasil uji Wilcoxon menyatakan bahwa pemberian dental health education dengan permainan simulasi yang memuat pengetahuan tentang kesehatan gigi dan mulut dapat memberi pengaruh terhadap peningkatan pengetahuan anak tentang kesehatan gigi dan mulut. Hal ini sejalan dengan penelitian yang dilakukan oleh Sumantri et al. ${ }^{7}$ yang menunjukkan bahwa ular tangga sebagai permainan edukasi kedokteran gigi berpengaruh terhadap peningkatan pengetahuan kesehatan gigi dan mulut anak di Sekolah Dasar Kecamatan Mandiangin Koto Selayan Kota Bukittinggi.

Metode pembelajaran ini merupakan salah satu dari beberapa metode simulasi. Metode ini menyajikan pengalaman belajar dengan menggunakan situasi tiruan atau mendekati pengalaman konkret yang dalam teori kerucut Edgar Dale seseorang dapat mengingatnya $90 \% .^{9}$ Karakteristik metode permainan simulasi dapat menciptakan suasana belajar yang menyenangkan. Metode ini digunakan agar tujuan belajar dapat dicapai secara efektif dan efisien dalam suasana gembira meskipun membahas hal-hal yang sulit. ${ }^{8}$ Permainan ular tangga merupakan salah satu permainan tradisional yang mudah dibuat, murah, dan biasa dilakukan oleh anak-anak dengan bentuk strategi pembelajaran yang efektif melalui pendekatan aktif, kreatif, efektif dan menyenangkan sehingga anak akan lebih tertarik dalam proses pembelajaran. ${ }^{9}$

Hasil uji Mann-Whitney (Tabel 8) menunjukkan bahwa terdapat perbedaan bermakna antara kelompok ceramah dan kelompok yang diberikan dental health education dengan metode simulasi permainan ular tangga $(\mathrm{p}=0,000<0,05)$. Melalui data ini dapat dilihat bahwa pemberian dental health education dengan metode permainan simulasi sangat besar pengaruhnya terhadap peningkatan pengetahuan anak tentang kesehatan gigi dan mulut, sehingga dapat dikatakan lebih efektif dibandingkan dengan metode ceramah. Hal ini ditunjukkan melalui nilai rata-rata kelompok tersebut yaitu sebesar 38,48 , sedangkan pada kelompok ceramah hanya sebesar 16,52.

Dalam hal ini peneliti berpendapat bahwa pemberian dental health education dengan menggunakan metode simulasi permainan ular tangga yang memuat informasi tentang cara menyikat gigi yang benar, waktu menyikat gigi yang tepat, frekuensi menyikat gigi, waktu yang tepat mengunjungi dokter gigi, dan makanan yang baik maupun yang tidak baik untuk kesehatan gigi dan mulut, berefek baik dalam meningkatkan pengetahuan tentang kesehatan gigi dan mulut. Metode ini dapat digunakan sebagai media belajar sambil bermain bagi anak, sehingga dapat 
memotivasi anak untuk belajar.

Selain dapat memotivasi anak dalam proses pendidikan terutama penggunaan media grafis yaitu media yang menuangkan pesan dalam bentuk tulisan, huruf, gambar, dan simbol yang mengandung arti, seseorang dapat melibatkan lebih dari satu panca indra. Semakin banyak indra yang digunakan maka semakin baik bahkan semakin banyak pesan atau informasi yang diperoleh. $^{7}$ Pada hakekatnya manusia belajar melalui enam tingkatan, dan dari apa yang dilihat dan didengar manusia dinyatakan belajar sebanyak $50 \% .^{10}$

Penelitian ini sejalan dengan penelitian yang dilakukan oleh Putri 2013 yang menyatakan bahwa terdapat perbedaan antara pengetahuan anak tentang keamanan makanan jajanan sekolah setelah diberikan penyuluhan dengan metode ceramah dan permainan edukatif ular tangga di SDN Soropadan Karangasem Surakarta. Dari hasil penelitiannya, tingkat pengetahuan siswa sekolah tentang keamanan makanan jajanan sekolah setelah diberikan penyuluhan dengan metode permainan edukatif ular tangga sebagian besar baik yaitu sebanyak $87,1 \%$, bila dibandingkan dengan metode ceramah yang hanya sebesar $77,4 \%$ dapat menangkap pengetahuan tersebut. ${ }^{10}$

Proses pembelajaran, pengembangan materi dapat dilakukan dengan berbagai cara, salah satunya ialah dengan optimalisasi media. Media pembelajaran pada mulanya hanya dianggap alat bantu guru dalam kegiatan mengajar, dengan tujuan untuk memberikan pengalaman yang lebih konkret, memotivasi serta meningkatkan daya serap, serta daya ingat siswa dalam belajar. ${ }^{9}$ Penggunaan media ular tangga dapat diberikan kepada anak sekolah dasar karena memiliki keunggulan yaitu mudah dimainkan, anak belajar untuk bekerja sama dan berkompetisi yang sehat, bersosialisasi dengan teman sebaya, serta bermain sambil belajar.

\section{SIMPULAN}

Dari hasil penelitian yang dilaksankan di SDN Mantelagheng dapat disimpulkan bahwa pemberian DHE dengan metode ceramah dan metode permainan simulasi efektif meningkatkan pengetahuan kesehatan gigi dan mulut anak. Metode permainan simulasi lebih efektif meningkatkan pengetahuan kesehatan gigi dan mulut anak dibandingkan dengan metode ceramah.

\section{SARAN}

1. Perlu dilakukan penelitian sejenis dengan menggunakan media pendidikan kesehatan yang berbeda atau dengan menambah media pendidikan kesehatan yang lain sebagai pembanding sehingga bisa diketahui jenis media yang paling memengaruhi dan paling efektif untuk membantu menyampaikan informasi lewat pendidikan kesehatan.

2. Perlu dilakukan penelitian sejenis juga dilokasi yang berbeda, sehingga dapat dilihat daerah mana saja yang belum paham tentang kesehatan gigi dan mulut dan perlu dijangkau oleh tenaga kesehatan.

3. Diharapkan Dinas Kesehatan Kabupaten Kepulauan Sangihe dan Puskesmas di Kecamatan Tamako bisa menggunakan hasil penelitian ini sebagai informasi dalam upaya preventif dan promotif dalam bidang kesehatan gigi dan mulut untuk meningkatkan derajat kesehatan gigi di wilayah kerjanya.

\section{DAFTAR PUSTAKA}

1. Badan Penelitian dan Pengembangan Kesehatan Republik Indonesia. Laporan Hasil Riset Kesehatan Dasar (Riskesdas) nasional 2007. Jakarta: Kementrian Kesehatan Republik Indonesia, 2008; p.131-3.

2. Badan Penelitian dan Pengembangan Kesehatan Republik Indonesia. Laporan Hasil Riset Kesehatan Dasar (Riskesdas) nasional 2013. Jakarta: Kementrian Kesehatan Republik Indonesia, 2013; p.110-2.

3. NotoatmodjoS. Ilmu kesehatan masyarakat. Jakarta: Rineka Cipta, 2003; p.108-12.

4. Notoatmodjo S. Kesehatan masyarakat ilmu dan seni. Jakarta: Rineka Cipta, 2007; p. 32-7. 
5. Notoatmodjo S. Promosi kesehatan teori dan aplikasi. Jakarta: Rineka Cipta, 2010; p.16-8.

6. Susilana R, Riyana C. Media Pembelajaran. Bandung: Wacana Prima, 2009; p. 8.

7. Sumantri D, Yuniar L, Mustika A. Pengaruh perubahan tingkat pengetahuan kesehatan gigi dan mulut pada pelajar usia 7-8 yahun di 2 SD Kecamatan Mandiangin Koto Selayan Kota Bukittinggi melalui permainan edukasi kedokteran gigi. Andalas Dental Jurnal. 2013;1(1).

8. Mudlofir A, Rusydiyah EF. Desain Pembelajaran Inovatif. Jakarta: Raja Grafindo Persada, 2016; p. 115-7.

9. Kholid A. Promosi Kesehatan. Jakarta: Raja Grafindo Persada, 2012; p. 125-30.

10. Zainal. Model-model Media dan Strategi pembelajaran kontekstual (Inovatif). Bandung: Yrama Widya, 2013; p.13. 